\title{
Global Challenges, Global Opportunities: From Policy to Practice
}

And the same pallid moon tonight, Which rides so quietly, clear and high, The mirror of our pale and troubled gaze Raised to a cool Canadian sky.

Norman Bethune, Canadian Forum, July 1937

$\mathbf{T}^{2}$ remind the world of the critical importance of forests, the UN General Assembly declared 2011 the International Year of Forests. During the recent United Nations climate summit in Durban, South Africa, 11 members of the Collaborative Partnership on Forests hosted a Forest Day 5 seminar titled: "From Policy to Practice". The idea behind these seminars was for communities to share knowledge on forests and climate change and provide a forum for discussion on the complexity of issues surrounding climate change. Attention was paid to the design of climate initiatives in mitigating and adapting to climate change in African Forests. Eduardo Rojas-Briales, the Assistant Director-General of the Forestry Department, FAO, noted "We are aware that, in applying sustainable forest management principles and practices for climate change mitigation and adaptation, we can at the same time further goals for sustainable livelihoods, biodiversity and environmental sustainability."

At the summit, a news release by the Center for International Forestry Research (CIFOR) stated: "Deforestation and land use change contribute an estimated 12 to $18 \%$ of the worlds total annual carbon emissions." Francis Seymour, Director General of CIFOR continued, "We urgently need a strong and sustained effort focused on forest management and governance, given the crucial role of forests in confronting some of the most important challenges of our time: climate change, poverty, and food security." To tackle these issues with action, the world's largest consortium of agricultural researchers embarked on a 10-year global research program focusing on forests and agro-forestry. Tony Simons, Director General of the World Agroforestry Center estimates, "Roughly $10 \%$ percent of the world's tree cover is found on farms," and "In developing countries, agroforestry systems also are providing cheap and nutritious fodder for animals along with non-timber forest products, like nuts and fruit, that boost farm incomes, particularly in households headed by women." Areas like sub-Saharan Africa have witnessed an overharvest of trees for firewood and charcoal contributing to forest degradation and these types of "unsustainable management practices are also a major contributor to the desertification of formerly forested areas and have played a role in the famine now plaguing the horn of Africa." This 10-year global research program includes an initial three-year budget of US\$233 million and is one of 15 programs developed and funded by the Consultative Group on International Agricultural Research (CGIAR). Already, nine programs have been approved at a cost of US $\$ 2.27$ billion "aimed at improving food security and the sustainable management of the water, soils and biodiversity that underpin agriculture in the world's poorest countries."

Closer to home, Don Roberts, ViceChairman of CIBC World Markets Inc. was invited by the Alberta School of Forest Science and Management to speak at the $66^{\text {th }}$ Forest Industry Lecture Series on November 10, 2011. Robert's presentation was on "The Global Competition for Land: The 4Fs (Food, Feed, Fibre and Fuel)." Roberts described how the convergence of markets for food, fuel and fibre are the key drivers for the bio-economy with productive land being the common element behind the move towards environmental, economic and national security. Considering that the United Nations is forecasting the global population to increase a third by 2050 , it is expected that land per capita will decrease by as much as $25 \%$. Roberts cited an International Institute for Applied Systems Analysis (IIASA) study by Fisher et al. in 2009 that linked bio-energy and food prices, noting that if all global bio-energy targets are

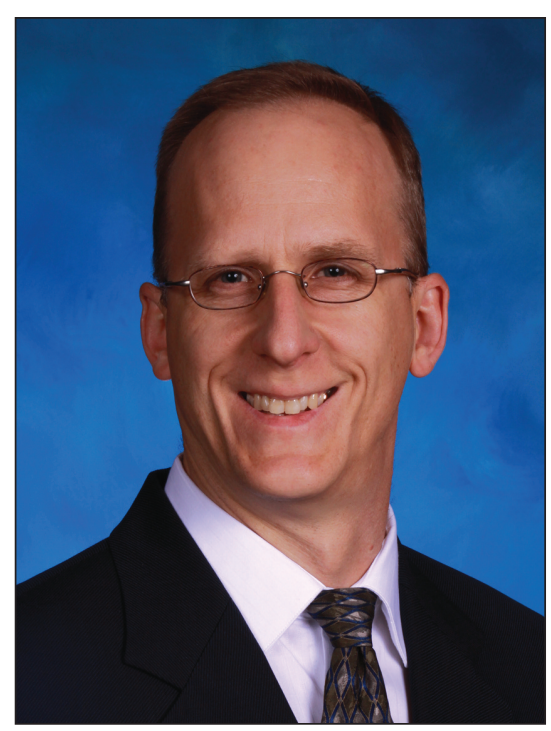

Mark Kube, R.P.F. CIF/IFC President/président

implemented, a doubling of food demand and tripling of energy use would result. This would lead to crop prices increasing by $30 \%$ and markets responding in three key areas: enormous pressure on the demand for better quality pasture land and timberland; stimulating production of traditional agricultural products and energy crops and rising costs for key food ingredients. Land-use patterns would shift as prices trend upwards to meet market place demand. Convergence is expected to be greatest in the southern hemisphere due to higher crop yields and lower labour costs; however, there will also be pressure on some of the best forestlands to supply food or bio-energy crops. To put this in context, 10 billion US dollars have been invested annually in biomass plants since 2005 despite the recent recession. Roberts pointed to one dominant reason-public policy. China expects to increase biomass production from 6GW in 2010 to $24 \mathrm{GW}$ in 2020 at a cost of 70 billion US dollars. China accounts for $24 \%$ of the global biomass investment. Canada invests slightly less than $2 \%$. The European Union plans to double its biomass capacity from $13 \mathrm{GW}$ to $26 \mathrm{GW}$ at a cost of 50 billion US and 
Brazil is phasing out manual harvesting of sugarcane to mechanize its biomass delivery systems.

The United States dominates biomass non-food biofuel investment at $55 \%$ of total global asset financing. Canada remains comfortable at $2 \%$. The U.S. Government's Renewable Standard 2 is driven by its desire to be energy secure and will ultimately bring forward the next generation of biofuels. By 2022, the US target is 21 billion gallons of advanced biofuels, 20 billion more than 2010. Approximately 16 billion gallons will come from advanced cellulosic biofuels. Given our shared infrastructure and refining capacity, North American private energy companies will ulti- mately finance these projects. Don Roberts showed how a low-cost biopathway is able to compete with traditional hydrocarbons and that central to all bio-energy strategies is a competitive price for delivered biomass. As forest professionals, this will become one of the forest sector's main challenges in a globally competitive landscape.

\section{Défis mondiaux, opportunités mondiales : De la politique à la pratique}

And the same pallid moon tonight, Which rides so quietly, clear and high, The mirror of our pale and troubled gaze Raised to a cool Canadian sky.

Norman Bethune, Canadian Forum, Juillet 1937

A fin de rappeler au monde l'importance des forêts, l'Assemblée générale des Nations unies avait déclaré 2011 l'Année internationale des Forêts. Au cours de la récente conférence sur les changements climatiques tenue à Durban en Afrique du Sud, 11 membres du Collaborative Partnership on Forests ont organisé un colloque sur les forêts au cours de la cinquième journée, intitulé : " De la politique à la pratique ». Lobjectif de ce colloque était de permettre aux communautés de partager leurs connaissances sur les forêts et les changements climatiques et de constituer un forum pour discuter de la complexité des enjeux rattachés aux changements climatiques. Lattention a porté sur la conception des projets de réduction et d'adaptation aux changements climatiques dans les forêts africaines. Eduardo Rojas-Briales, le directeur général adjoint du Département de Foresterie de la FAO a souligné que : " Nous sommes conscients quen appliquant les principes et les pratiques d'aménagement forestier durable afin d'atténuer et de s'adapter aux changements climatiques, nous pouvons par la même occasion atteindre des objectifs permettant des conditions de vie durables, le maintien de la biodiversité et la durabilité de l'environnement. »

Lors du sommet, un communiqué émis par le Center for International Forestry Research (CIFOR) mentionnait : « La déforestation et les changements d'utilisation du territoire contribuent selon les estimations entre 12 et
$18 \%$ des émissions globales annuelles de carbone. » Francis Seymour, Directeur général du CIFOR indiquait que : " Nous devons impérativement nous consacrer attentivement et de façon soutenue à l'aménagement et l'intendance des forêts, étant donné leur rôle crucial qu'elles jouent face aux plus importants défis de notre époque : les changements climatiques, la pauvreté et l'approvisionnement en nourriture. " Pour résoudre ces enjeux par des actions concrètes, le plus important consortium de chercheurs en agriculture de la planète, a démarré un programme mondial de recherche sétalant sur 10 ans et portant principalement sur les forêts et l'agroforesterie. Tony Simons, Directeur général du World Agroforestry Center estime : " qu'environ $10 \%$ du couvert forestier de la planète se retrouve parmi les sites agricoles, » et que " dans les pays en voie de développement, les systèmes agroforestiers produisent également des fourrages peu dispendieux et nutritifs pour les animaux ainsi que des produits forestiers non ligneux, comme des noix et des fruits, qui accroissent les revenus agricoles, particulièrement dans le cas des ménages gérés par des femmes. » Des régions comme celle de l'Afrique sub-saharienne ont connu une surexploitation des arbres utilisés comme bois de cuisson et pour la production de charbon de bois, ce qui a contribué à la dégradation des forêts tout en étant « des pratiques d'aménagement insoutenables qui s'avèrent être également un élément important de désertification de ces territoires autrefois boisés, tout en jouant un rôle dans la famine qui sévit dans la Corne de l'Afrique. " Ce programme mondial de recherche de 10 ans comporte un budget initial de 3 ans sélevant à 233 millions \$us et constitue l'un des 15 programmes élaborés et financés par le Consultative Group on International Agricultural Research (CGIAR). À ce jour, neuf programmes ont déjà été approuvés pour un montant total de 2.27 milliards \$us « visant à améliorer l'approvisionnement en nourriture et la gestion durable de l'eau, des sols et de la biodiversité qui sont à la base de l'agriculture des pays les plus pauvres de la planète. "

Plus près de chez nous, Don Roberts, Vice-président des Marchés mondiaux de la CIBC, était l'invité de l'École des Sciences forestières et de l'Aménagement de l'Alberta lors de la $66^{\mathrm{e}}$ Conférence de l'Industrie forestière tenue le 10 novembre 2011. L'exposé de M. Roberts s'intitulait « The Global Competition for Land: The 4Fs (Food, Feed, Fibre and Fuel). » Roberts a décrit comment la convergence des marchés au niveau de l'alimentation, du bois de cuisson et de la fibre constituent les éléments clés de la bio-économie tout en ayant les territoires productifs comme dénominateur commun de ce mouvement de recherche de protection environnementale, économique et territoriale. En tenant compte que les Nations unies envisage un accroissement de la population mondiale d'un tiers d'ici 2050, on prévoit que la superficie per capita sera réduite de près de $25 \%$. Roberts a fait référence à une étude de l'International Institute for Applied Systems Analysis (IIASA) réalisée par Fisher et al. en 2009 qui établissait des liens entre la bioénergie et les prix des aliments, pour souligner que si les objectifs mondiaux de bioénergie étaient mis en œuvre, il en résulterait un doublement de la demande d'aliments et un triplement de la consommation 
énergétique. Cela entraînerait une augmentation des prix des récoltes de $30 \%$ et une réaction des marchés selon trois aspects déterminants : une pression accentuée de la demande d’accès à des pâturages et des territoires forestiers de meilleure qualité; une stimulation de la production de produits agricoles traditionnels et de récoltes destinées à des fins énergétiques et un accroissement des prix des denrées alimentaires de base. Les schémas d'utilisation du territoire seraient modifiés en fonction de la hausse des prix afin de répondre aux demandes des marchés. La convergence serait plus accentuée dans l'hémisphère austral à cause des plus forts rendements de production et des plus faibles coûts de main d’euvre, mais il y aura également des pressions exercées sur certains des meilleurs territoires forestiers pour produire des aliments et des récoltes destinées à des fins énergétiques. À titre d'exemple concret, 10 milliards \$us ont été investis annuellement dans la production de biomasse depuis 2005 et ce malgré la récente récession. Roberts a souligné l'un des facteurs dominants - les politiques publiques. La Chine prévoit accroître la production de biomasse de $6 \mathrm{GW}$ en 2010 à $24 \mathrm{GW}$ en 2020 en investissant 70 milliards \$us. La Chine totalise 24\% des investissements mondiaux en biomasse. Le Canada totalise en peu moins de $2 \%$. L'Union européenne prévoit doubler sa capacité en biomasse de $13 \mathrm{GW}$ à $26 \mathrm{GW}$ en investissant 50 milliards \$us et le Brésil modifie la récolte manuelle de la canne à sucre afin de mécaniser ses systèmes d'approvisionnement en biomasse.

Les États-Unis dominent les investissements en biomasse non destinée à l'alimentation en accaparant 55\% des investissements mondiaux. Le Canada demeure confortablement à $2 \%$. La politique intitulée "Renewable Standard 2 " du gouvernement américain répond à leur désir de sécuriser leurs approvisionnements énergétiques et permettra de ce fait lintroduction d'une nouvelle génération de biocarburants. Les É.-U. visent d'ici 2022 la production de 21 milliards de gallons de biocarburants de nouveaux types, soit 20 milliards de plus quactuellement. Près de 16 milliards de gallons proviendront de biocarburants dorigine cellulosique. Étant donné le partage des infrastructures et des installations de raffinage, les compagnies privées de production énergétique de l'Amérique du Nord seront appelées à financer ces projets. Don Roberts a démontré comment la filière des produits bioénergétiques à faibles coûts est en mesure de rivaliser avec les hydrocarbures traditionnels et que l'intérêt de toutes les stratégies bioénergétiques repose sur le coût compétitif d'approvisionnement en biomasse. En tant que professionnels de la foresterie, cela constitue l'un des principaux défis du secteur forestier à léchelle de la compétition mondiale.

\section{OF RELEUANGE $\vdots$ QUESTION D'INFORMATION}

\section{Totem Plants 100000 Seedlings in the Slave Lake Region}

his achievement by Totem Building

Supplies Ltd. of Western Canada was announced in the November/December Chronicle. It marked the planting of the $100000^{\text {th }}$ seedling out of a planned 1 million in the Slave Lake region. CIF/IFC President Mark Kube interviewed Totem's Vice President and General Manager, Dave Carr, on the company's program.

Mark Kube: CIF/IFC members are impressed with Totem's initiative to plant trees in Alberta in support of sustainable forest management and we are pleased to be partnering with Totem with the sale of Clean Air Tree kits in all of your outlets. What has been the reaction of your customers to what you are doing over all with tree planting and in particular with the clean air tree kits?

Dave Carr: Weve found that our customers have been very receptive and eager to get involved in this progressive initiative. The purchase of every Clean Air Tree kit results in the planting of three trees; one in their very own back-

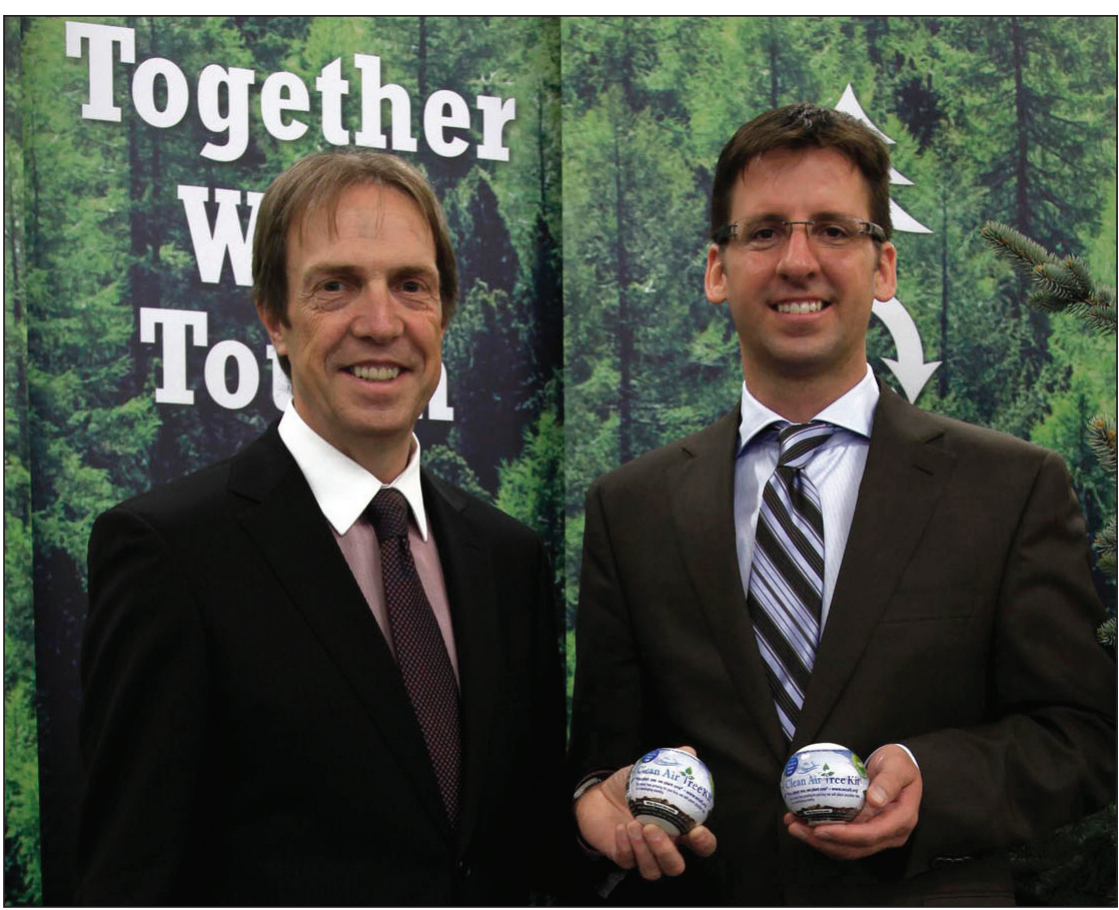

Claude Bernier (left), Executive Vice President, Marketing and Customer Innovations, RONA inc., and Dave Carr (right), Vice President and General Manager, TOTEM Building Supplies Ltd. 